\title{
Účinná l'útost' ako neobmedzená daňová amnestia?
}

\section{Effective Regret as an Unrestricted Tax Amnesty?}

\author{
Veronika Nováková*
}

\begin{abstract}
Abstrakt
Daňové prijmy sú jedným z dôle žitých finanöných prostriedkov, prostrednictvom ktorých sú zabezpečované verejné potreby občanov/obyvatelov štátu. Na to, aby tieto prijmy mobli plynút' do príslušných roapočtov je nevyhnutné, aby vznikajúce vațaby medzi státom a dañovým subjektom, boli náležite upravené v príslušnej právnej norme. Tieto daňovoprávne vąt'aby sú natol'ko dôležité pre štát, že zákonodarca počita $s$ možnostou dodatočného splnenia daňovej povinnosti namiesto samotnébo potrestania. Cielom tobto príspevku je podrobná sumarizácia a vývoj inštitútu úcinnej l'útosti všeobecne v oblasti dañovébo práva, pričom sa zobladñuje konanie daňovébo subjektu v rámci Daňovébo poriadku, ako aj samotný inštitút trestnébo práva - účinnú l’útost.' Ďalej príspevok analyzuje i dôležité skutočnosti prostredníctvom judikátov súdov, ktoré mali význammý uplyv na neskoršiu novelizáciu tobto inštitútu, a zároveň komparáciou právnej úpravy úcinnej lútosti v Českej republike poukázat’ na dôlę̌ité odlišnosti, k.toré sú osožné pre d’alšie návrby pre zlepšrenie úpravy. Teda v konečnom dôsledku sa príspevok pokíša zodpovedat' nel'abkú otázku, č inštitút úcinnej l'útosti mo:̌no z hladiska aktuálnej úpravy pova ̌̃ovat' za neobmedžnú daňovú amnestiu.
\end{abstract}

\section{Klíčová slova}

Zodpovednost'; delikt; účinná l'útost'.

\section{Abstract}

Tax revenues are one of the most important means of financing the public needs of citizens / residents of the state. In order for this revenue to flow into the relevant budgets, it is essential that the emerging relationships between the state and the taxpayer are appropriately regulated in the relevant legal norm. These tax-related relationships are so important that the legislator considers the possibility of additionally fulfilling the tax liability as punishment itself. The purpose of this contribution is to provide a detailed summary and development of an effective regret institution in the field of tax law, taking into account all forms of tax evasion of the tax entity's conduct under the Tax Code, as well as the actual criminal justice institute - an effective regret. In addition, the contribution analyses important facts through court rulings that have had a significant impact on the later revision of this institute and, at the same time, the comparison of the law of effective regret in the Caech Republic points to important differences that are relevant to further proposals for improved regulation. Thus, in the end, the contribution attempts to answer the inconsequential question of whether an institute of effective regret can be regarded as an unrestricted tax amnesty in terms of the current adjustment.

\section{Keywords}

Responsibility; Delict; Effective Regret.

\footnotetext{
* Veronika Nováková, doktorandka, Fakulta verejnej správy, Univerzita Pavla Jozefa Šafárika v Košiciach, Slovensko / PhD. student, Faculty of Public Administration, Pavol Jozef Šafárik University in Košice, Slovak Republic / E-mail: veronika.novakova@student.upjs.sk
} 


\section{Úvod}

Ked’že štát potrebuje financie na zabezpečenie dôležitých verejných potrieb, je nevyhnutné, aby legálne získal prostriedky na ich dosiahnutie. Práve jedným zo spôsobov získavania finančných prostriedkov je i ukladanie a výber daní, zakotvené v čl. 59 Ústavy Slovenskej republiky, zákon č. 460/1992 Zb. v znení neskorších predpisov. Tento samotný inštitút pri vzniku určitej daňovej povinnosti, vel’mi výrazne zasahuje do majetkových, resp. osobných práv fyzických osôb i právnických osôb, preto je nevyhnutné, aby úprava tohto inštitútu bola exaktná. Dovolujeme si tvrdit', že ked’že ide o zásah do práv fyzických a právnických osôb na jednej strane, zároveň to znamená však pre štát nárok na túto peňažnú čiastku, a preto je i nevyhnutné zabezpečit’, aby takýto nárok bol plne vymožitel'ný štátom. To v konečnom dôsledku znamená, že v prípade neplnenia povinnosti fyzických osôb a právnických osôb, ktorým vzniká daňová povinnost', je nevyhnutné vyvodit' zodpovednost' za porušenie takejto povinnosti. Teda sa náležite potrestá páchatel' za neplnenie daňovej povinnosti, z hl'adiska dôležitosti chráneného záujmu spoločnosti prostriedkami daňového práva, čo znamená, že sa dopustí správneho deliktu. Avšak ak ohrozil alebo porušil tak dôležitý záujem spoločnosti, že sa dopustil trestného činu, je potrebné plne využit’ prostriedky trestného práva.

Hned' v úvode je potrebné však zdôraznit', že v oblasti daňového práva nie je uplatnitel'nost' predchádzajúceho odseku vždy tak jednoznačná. Pre zodpovednost' v daňovom práve sú typické najmä dve funkcie, ktoré tvoria akýsi nevyvážený vzt’ah, kde represívnu funkciu oslabuje fiškálna funkcia. Teda miera uplatnenia represívnej funkcie bude vyvažovaná ochranou fiškálneho záujmu verejných rozpočtov. To znamená, že zákonodarca dáva celý rad možností, ako zvrátit' konanie páchatel'a, aby ho napravil a náležite si plnil daňovú povinnost'.

Ciel'om tohto príspevku je podrobná sumarizácia a vývoj inštitútu účinnej lútosti všeobecne $\mathrm{v}$ oblasti daňového práva, pričom zohl'adňuje protiprávne konanie daňového subjektu v rámci Daňového poriadku, ako aj samotný inštitút trestného práva - účinnú l'útost'. Ďalej príspevok analyzuje i dôležité skutočnosti prostredníctvom judikátov súdov, ktoré mali významný vplyv na neskoršiu novelizáciu tohto inštitútu, a zároveň komparáciou právnej úpravy účinnej lútosti v Českej republike poukázat' na dôležité odlišnosti, ktoré sú osožné pre d’alšie návrhy pre zlepšenie úpravy. Teda v konečnom dôsledku sa príspevok pokúša zodpovedat' nel'ahkú otázku, či inštitút účinnej lútosti možno z hladiska aktuálnej úpravy považovat’ za neobmedzenú daňovú amnestiu.

\section{Možnosti zániku trestnosti konania daňového subjektu}

Ako sme už $\mathrm{v}$ úvode načrtli $\mathrm{v}$ daňovom práve dochádza $\mathrm{k}$ vyvažovaniu dvoch funkcií daňového práva, represívnej funkcie a fiskálnej funkcie. Práve toto vyvažovanie je možné vnímat' i v rámci celého textu Daňového poriadku, zákona č. 563/2009 Z. z. 
o správe daní (Daňový poriadok) v znení neskorších predpisov. Zväčša však možno vnímat' skôr potlačenie represívnej funkcie nad fiskálnou. Toto potlačenie represívnej funkcie pred fiskálnou naznačuje samotný obsah Daňového poriadku a jej nasledujúce inštitúty. $\mathrm{Na}$ druhej strane však je potrebné zdôraznit', že štát dáva daňovému subjektu možnost', aby ak niečo neurobil riadne ( $\int 17$ Daňového poriadku) alebo niečo zmeškal ( $\int 29$ a Daňového poriadku), mohol si dosiahnut' i napriek nedostatkom, ochranu svojich práv. V niektorých prípadoch hoci samotné znenie príspevku vykazuje dojem, že štát len chce zabezpečit' dostatok výnosov z daní, sa nevylučuje uplatnenie obidvoch funkcií naraz. Ide len o zvýraznenie existencie ospravedlnitel’ných prekážok daňového subjektu, aby $\mathrm{v}$ konečnom dôsledku došlo k riadnemu splneniu povinností.

\17 ods. 1 upravuje výzvu na odstránenie nedostatkov daňového priznania, „ak má správca dane pochybnosti o správnosti, pravdivosti alebo úplnosti podanébo dañovébo priznania alebo jeho príloh (d’alej len „nedostatky daňovébo priz̨nania“), vyzue daňový subjekt na ich odstránenie."

\29 ods. 1a 2 zmeškanie lehoty v dikcii: „Správca dane zo závažných dôvodov odpustí żmeškanie lehoty, ak o to daňový subjekt pořiada najneskôr do 30 dni odo dña, ked'odpadli dôvody żmeškania, a ak v tej istej lehote urobi zmeškaný úkon. Zmeškanie ǔ̌predľ̌enej lehoty nemožno odpustit. Zmeškanie lehoty nemožno odpustit', ak uplynul od posledného dña pôvodnej lehoty jeden rok.."

Určitou špecifickou činnost'ou je určenie dane podl'a pomôcok $\int 48$ ods. 1, a to najmä v prípade, „ak daňový subjek.t nepodá daňové priznanie ani na výzvu správcu dane, nesplni pri preukazovani nim wádzaných skutočnosti niektorú zo svojich zákonných povinností, v dôsledku coho nemožno daň správne zistit', alebo neumožni vykonat' daňovú kontrolu; to neplatí, ak ide o daňoví kontrolu podla \46 ods. 2. "Hoci z uvedeného odseku sa môže zdat', že dochádza k nadradeniu fiskálnej funkcie nad represívnou, v danom prípade sa uplatnia obe naraz. Správca dane vyrubí daň za daňový subjekt, čo môže navodzovat' dojem dominancie fiskálnych záujmov štátu, na druhej stráne však zároveň správca dane uloží daňovému subjektu pokutu podl'a \154 ods.1 písm. a) v spojení s \ 155 ods. 1 písm. a) a b) Daňového poriadku. Daňový poriadok v ods.5 však zdôrazňuje, že pri určení dane podl'a pomôcok je správca dane povinný prihliadnut' tiež na zistené okolnosti, z ktorých vyplývajú výhody pre daňový subjekt, aj ked’ ním neboli uplatnené. Výsledkom tohto procesu je protokol, ku ktorému sa má možnost' daňový subjekt vyjadrit', a to najmä k tomu, či bol dodržaný zákonný postup, resp. či boli uplatnené zvýhodnenia pre daňový subjekt. Ďalším inštitútom je i záložné právo, ktoré slúži k zabezpečeniu daňového nedoplatku rozhodnutím správcu dane, pričom samotný postup je upravený v \81 a nasl. Daňového poriadku.

V neposlednom rade je potrebné spomenút' aj \154 ods. 2 Daňového poriadku, ktorý do určitej miery nepriamo upravuje deliktuálnu zodpovednost', prostredníctvom vymedzenia podmienok, za ktorých je možné zbavit’ sa zodpovednosti za porušenie povinnosti, ak sa preukáže, že zo závažných zdravotných dôvodov alebo v dôsledku iných 
okolností hodných osobitného zretel'a, ktoré fyzická osoba-nepodnikatel' nemohla ovplyvnit' svojím konaním. Avšak ak odpadnú dôvody, na základe ktorých sa daňový subjekt zbavil tejto zodpovednosti, je nevyhnutné, aby dodatočne svoje povinnosti splnil. Teda do určitej miery i Daňový poriadok pripúšt'a možnosti liberácie. Vernarský však poukazuje na skutočnost', že tieto liberačné dôvody sú v rozpore s Odporúčaním Výboru ministrov Rady Európy (2007)7 o dobrej správe a právo na spravodlivý proces z 20. júna 2007, najmä s princípom rovnosti ako princípom dobrej správy, pretože dochádza tu k nerovnakému zaobchádzaniu k fyzickej osobe-nepodnikatelovi, fyzickej osobe-podnikatel'ovi a právnickej osobe. Teda zastávame názor, že zákonodarca by mal bud' toto ustanovenie vymazat' alebo definovat' ospravedlnitel'né dôvody i pre fyzickú osobu- podnikatel’a, či právnickú osobu. ${ }^{1}$

Toto oslabenie je možné vnímat’ aj v zmysle \ 155 ods. 7 Daňového poriadku, ak daňový subjekt $\mathrm{v}$ riadnom daňovom priznaní si neoprávnene znížil daňovú povinnost', avšak dodatočne podá opravené daňové priznanie, ešte predtým než sú prostriedky vyplatené z verejných rozpočtov, správca dane mu sankciu neuloží. Ked’že dodatočným podaním daňového priznania znížil svoje nároky voči verejným rozpočtom, represívny charakter zodpovednosti v daňovom práve sa neuplatní, pretože „vyhrala“ fiškálna funkcia, aj za cenu nesplnenia povinnosti daňového subjektu, včas podat' úplné a pravdivé daňové priznanie. ${ }^{2}$

Ďalšie vyvažovanie fiskálnej funkcie nad represívnou možno vnímat’ z hl'adiska už samotného následku porušenia povinnosti, kedy daňovému subjektu môže byt' uložená pokuta alebo úrok z omeškania. Daňový poriadok tieto dva inštitúty vel’mi podrobne vymedzuje, pričom pripúšt'a aj za taxatívne stanovených podmienok úl'avy zo sankcie, čo možno považovat' za opätovné potvrdenie nadriadenosti fiskálnej funkcie nad represívnou, teda uprednostnenie dodatočného plnenia daňovej povinnosti, pred uložením sankcie.

Daňový poriadok d'alej určuje, kedy správca dane neuloží pokutu, čím zákonodarca určuje hranicu rentability ukladania pokút, kedy správcovi dane určuje hranicu nepresiahnutia $5 €$, pričom osobitne pamätá na obec ako správcu dane, kde hranica rentability vymáhania dodatočného plnenia povinností musí presiahnut' 3 eurá.

\section{2 Úl’ava zo sankcie alebo odpustenie sankcie}

Daňový poriadok upravuje aj možnost' úl'avy zo sankcie alebo odpustenie sankcie za explicitne stanovených podmienok. Práve táto čast', sa môže na prvý pohl'ad vzdat', že s problematikou príspevku nesúvisí, avšak chceme poukázat' na to, že v rámci

1 VERNARSKÝ, Martin. Funkcie zodpovednosti za porušenie povinností podl’a daňového poriadku. In: Zbornik prispevkov z. medzinárodnej vedeckej konferencie 12. novembra 2013, Trestnoprávna a administrativnoprávna zodpovednost'. Trnava: Právnická fakulta Trnavskej univerzity v 'Trnave, Katedra správneho práva, práva životného prostredia a finančného práva, 2014, s. 288.

2 Ibid. 
vyvažovania fiskálnej a represívnej funkcie vstupujú i iné parciálne funkcie, ktoré do určitej miery v konečnom dôsledku ovplyvňujú toto vyvažovanie. Nižšie spomínané dôvody úl’avy zo sankcie alebo odpustenie sankcie vykazujú do značnej miery znaky solidarity správcu dane s daňovým subjektom, resp. na neho odkázaných osôb. Logicky však z toho vyplýva, že správca dane by mal radšej znížit' alebo odpustit’ sankciu, ako svojho potenciálneho budúceho „daňovníka“ touto pokutou zlikvidovat' alebo ohrozit' jeho výživu alebo osôb na neho odkázaných. Teda pokial’ by správca dane neul'avil alebo neupustil od represie znamenalo by to, že sa v budúcom období fiskálna funkcia na tieto daňové subjekty už nemôže uplatnit'.

V závislosti od výšky sankcie udel’uje úl'avu zo sankcie alebo odpustenie sankcie iný správca dane, z hl'adiska prehl'adnosti, uvádzame nasledujúcu tabul'ku:

\begin{tabular}{|l|l|}
\hline $\begin{array}{l}\text { Správca dane oprávnený } \\
\text { na úl'avu/odpustenie }\end{array}$ & Výška uloženej sankcie \\
\hline \multirow{2}{*}{ Ministerstvo financií SR } & Fyzická osoba, ak presiahne sumu vyššiu ako $160000 €$ \\
\cline { 2 - 2 } & Právnická osoba, ak presiahne sumu vyššiu ako $1660600 €$ \\
\hline \multirow{2}{*}{ Finančné riaditel'stvo } & Fyzická osoba, ak nepresiahne sumu $160000 €$ \\
\cline { 2 - 2 } & Právnická osoba, ak nepresiahne sumu $1660600 €$ \\
\hline \multirow{2}{*}{ Daňové úrady a Colné úrady } & Fyzická osoba, ak nepresiahne sumu $32000 €$ \\
\cline { 2 - 2 } & Právnická osoba, ak nepresiahne sumu $332000 €$ \\
\hline Obec & bez limitu \\
\hline
\end{tabular}

Zdroj: vlastné spracovanie podl’a \157 Daňového poriadku

Dôvody úl'avy zo sankcie alebo odpustenie sankcie uvedené v žiadosti daňového subjektu, o ktorej rozhodne príslušný správca dane podl'a \157 Daňového poriadku sú nasledovné:

- ak daňový subjekt preukáže, že by zaplatením sankcie bola vážne ohrozená výživa daňového subjektu alebo osôb odkázaných na jeho výživu,

- ak právnická osoba, preukáže, že by zaplatenie sankcie viedlo k ukončeniu jeho činnosti a výnos z jeho likvidácie by bol pravdepodobne nižší než vyrubená sankcia,

- ak fyzická osoba-podnikatel’ preukáže, že by zaplatenie sankcie viedlo k ukončeniu jeho činnosti,

- ak daňový subjekt nesprávne vykázal daňovú povinnost', alebo nesplnil povinnost' $\mathrm{v}$ lehote ustanovenej podl'a tohto zákona alebo osobitných predpisov z dôvodu nesprávneho uplatňovania právneho predpisu.

Bezpodmienečnou podmienkou na to, aby mohla byt' daňovému subjektu uložená úl’ava, je preukázanie zaplatenia dane, pre ktorú mu bola sankcia vyrubená. 
Na žiadost' daňového subjektu môže byt' po preskúmaní príslušným správcom dane a zohladnení osobitných predpisov vydané:

- rozhodnutie, v prípade, že príslušný správca dane povolil úl'avu zo sankcie alebo odpustenie sankcie, pričom nie je možné podat’ riadny opravný prostriedok;

- oznámenie, v prípade nevyhovenia žiadost' daňového subjektu.

Neposlednom rade skutočnost'ou, na ktorú je potrebné poukázat', je aj dvojaký meter $\mathrm{v}$ právomociach správcu dane ukladat' sankcie za porušenie povinností. Obec ako správca dane je oprávnená ukladat’ za daňové delikty rádovo nižšie pokuty ako správca dane - orgán štátnej správy. Ani dôvodová správa k Daňovému poriadku nevysvetl'uje dôvod nižších pokút. Nie je jasné, čo tým zákonodarca chcel dosiahnut'. Vysvetlením by možno mohol byt' nižší výnos z daní v obci, resp. celkové príjmy do obecného rozpočtu. V opačnom prípade by došlo k podceneniu ochrany daňových príjmov obcí, ako aj ich fiskálnych záujmov prisúdením nižšej miery závažnosti porušeniu povinností daňového subjektu na úrovni obecnej samosprávy. Možno súhlasit' s názorom, že súčasná úprava bez právneho zdôvodnenia nie je akceptovatel'ná. ${ }^{3}$

\section{Zánik trestnosti páchatel'a}

Tak ako pri daňovoprávnej zodpovednosti dochádzalo k vzájomnému vyvažovaniu represívnej funkcie a fiškálnej funkcie, tak aj pri trestnoprávnej zodpovednosti štát uprednostňuje splnenie povinnosti pred trestným daňovým postihom aj prostredníctvom právneho inštitútu účinnej l'útosti.

Dôvodmi zániku trestnosti sú podl’a Trestného zákona (300/2005 Z. z.):

a) Zmena zákona ( $\left.\int 84\right)$,

b) Účinná l'útost'(\ 85 a \86),

c) Premlčanie trestného stíhania (\$ 87 a \88),

d) Premlčanie trestného stíhania u mladistvých (\$ 96).

Osobitne však medzi dôvody zániku trestnosti môžeme zaradit’ aj smrt’ páchatel'a, ktorá sa síce v Trestnom zákone neuvádza, avšak Trestný poriadok, z. č. 301/2005 Z. z. v znení neskorších predpisov, v \9 ods. 1 písm. d) zakotvuje, že „trestné stíhanie nemožno začat', a ak už bolo začaté, nemožno v ňom pokračovat' a musi byt' zastavené, proti tomu, kto zomrel alebo bol vyblásený za mítveho“. Rovnako ide aj o špeciálne dôvody zániku trestnosti pri vývojových štádiách úmyselných trestných činov, pokial’ išlo o štádium prípravy na zločin (\$ 13 ods. 3 TZ) alebo pokusu (\$14 ods. 3). ${ }^{4}$

3 VERNARSKÝ, Martin. Funkcie zodpovednosti za porušenie povinností podl’a daňového poriadku. In: Zbornik príspevkov z medzinárodnej vedeckej konferencie 12. novembra 2013, Trestnoprávna a administratívnoprávna zodpovednost'. Trnava: Právnická fakulta Trnavskej univerzity v Trnave, Katedra správneho práva, práva životného prostredia a finančného práva, 2014, s. 289.

4 IVOR, Jaroslav, Peter POLÁK a Jozef ZÁHORA. Trestnéprávo hmotné I. V šeobecná čast'. Bratislava: Wolters Kluwer (Iura Edition), 2016, s. 338. 
Zaujímavým prípadom je pre porovnanie, ak páchatel' spácha trestný čin, aj súd konštatuje vinu, ale v konečnom dôsledku dochádza k upusteniu od potrestania podl'a $\int 40$ Trestného zákona. Teda stáva sa z páchatel’a odsúdený v znení \$ 128 ods. 6 Trestného zákona, kedy „odsúdeným sa na účely tohto zákona rozumie páchatel, ktorý bol právoplatným rozsudkom uznaný za vinného. To neplatí, ak je odsúdenie zabladené." Pokial' dôjde k upusteniu od potrestania na páchatel'a sa podl'a \40 ods. 2 hl’adí ako keby nebol odsúdený. Tu sa naskytuje otázka, prečo je potrebné v tomto prípade konštatovat' vinu a v prípade účinnej l'útosti nie? Odpoved'ou mi mohol slúžit' \40 ods. 1, ktorý pripúšt’a upustenie od potrestania len $\mathrm{v}$ prípade prečinu, ak ním nebola spôsobená smrt' alebo t’ažká ujma na zdraví. V prípade účinnej l'útosti môžeme skonštatovat', že nejde o konanie ktoré by bezprostredne mohlo ohrozit' niekoho na živote alebo spôsobit' t'ažkú ujmu na zdraví. A d’alší dôležitým argumentom je to, že páchatel’ síce l’utuje svoje konanie, no nijako sa dobrovol’ne nepričinil, aby zamedzil ohrozeniu alebo poškodeniu chráneného záujmu. V prípade špecifickom ustanovení o účinnej l'útosti nemohol splnit' určujúce podmienky, lebo už sa dopustil prečinu, ktorý je nezvrátitel’ný.

Pre lepšie pochopenie rozdielov, je možné uviest' i 40 ods. 1 a to dôvody, kedy je možné upustit' od potrestania páchatel’a prečinu, ,ak:

a) páchatel' priznal spáchanie pré̌inu, jeho spáchanie l'utuje a prejavuje účinnú snahu po náprave a ak vzhl'adom na povahu spáchanébo prečinu a na doterajš život páchatel’a možno dôvodne očakávat', že už samotné prejednanie veci pred súdom postači na jeho nápravu,

b) prečin spáchala osoba z donútenia v priamej súvislosti s tým, že bol na nej spáchaný trestný čin obchodovania s l'ud'mi podl'a \179, trestný čin sexuálneho zneuživania podl'a 201 až 202, alebo trestný čin výroby detskej pornografie podla $\int 368$,

c) súd prijme záruku za nápravu páchatel'a a má za to, že văhladom na výchovný uplyv toho, k.to záruku ponúkol, povahu spáchanébo prečinu a osobu páchatel’a uloženie trestu nie je potrebné, alebo d) prečin spáchal v stave żmenšenej prícetnosti a súd má za to, že ochranné liečenie, ketoré mu zároveñ ukladá, zabezpeči ochranu spoloćnosti a nápravu páchatel'a úcinnejšie ako trest; to neplatí, ak si stav żmenšenej prícétnosti spôsobil uplyvom návykovej látky. "

\section{Historický exkurz úpravy účinnej l'útosti}

Predchádzajúci Trestný zákon č. 14/1961 Zb. v znení neskorších predpisov, upravoval inštitút účinnej l'útosti v $\int 66$, prostredníctvom taxatívneho výpočtu trestných činov, pri ktorých sa pripúšt’alo použitie tohto inštitútu. Taxatívne bol uvedený i trestný čin \148 skrátenia dane a poistného a $\int 148$ a neodvedenia dane a poistného. Pričom podmienky na splnenie účinnej l'útosti boli ovel'a prísnejšie a to v zmysle, že „trestnost' zaniká, ak páchatel' dobrovolne škodlivý následok trestnébo činu zamedzil alebo napravil, alebo urobil o trestnom čine oznámenie v čase, ked' škodlivému následku trestnébo činu moblo byt' ešte zabránené. "Pričom oznámenie bolo potrebné urobit’ na príslušnom orgáne činnom v trestnom konaní, v prípade vojakov bola výnimka, pretože ten to mohol oznámit’ velitel'ovi alebo náčelníkovi. Osobitným 
prípadom účinnej l'útosti, nachádzajúci sa v osobitnej časti trestného zákona, bol S 148ba, ktorý pripúšst'a zánik trestnosti trestného činu \148b nezaplatenie dane, ak splatná daň a jej príslušenstvo boli dodatočne zaplatené skôr, než sa otvorilo hlavné pojednávanie na súde.

Teda dôležité bolo, aby páchatel’ zamedzil, resp. zabránil vzniku škodlivého následku alebo dodatočne odstránil zmeny na chránenom záujme, kedy v podstate dochádzalo k obnoveniu pôvodného stavu. Čo v našom prípade znamená, že páchatel’ zaplatil skrátenú daň. Predchádzajúci trestný zákon nepripúšt'al možnost', že by páchatel nebol aktívny, práve naopak, vyžadoval aktívnu účast' páchatel'a. V prípade, že by bol škodlivý následok odstránený bez jeho pričinenia alebo prostredníctvom iných osôb alebo síl, neprichádzalo do úvahy použitie tohto ustanovenia. Avšak ak sa páchatel’ovi nepodarilo úspešne zamedzit' alebo napravit’ škodlivý následok, bolo možné v zmysle \33 písm. h) 'Trestného zákona to vyhodnotit' ako pol’ahčujúcu okolnost' alebo v zmysle \ 66 'Trestného zákona ako dôvod zániku nebezpečnosti činu pre spoločnost'. Neodmyslitel'nou podmienkou účinnej lútosti bolo, aby páchatel konal dobrovol’ne, to znamená z vlastnej vôle, avšak ak páchatel’a k tomuto inštitútu viedla len domnienka, že trestný čin bol odhalený, alebo, že už začalo trestné konanie, tento prejav vôle nespíňal kritéria dobrovol'nosti. Je potrebné dodat', že podl'a neskoršieho Trestného zákona \66 zanikali všetky trestné činy páchatel’a, ktoré boli v pomere subsidiarity k danému trestnému činu.

\section{Súčasná úprava inštitútu účinnej l'útosti}

Účinnú l'útost' je možné subsumovat' pod 'Tretiu hlavu zákona č. 300/2005 Z.z. Trestný zákon (d’alej trestný zákon) v znení neskorších predpisov, s nadpisom Zánik trestnosti. Všeobecne pod týmto inštitútom je možné vnímat' zákonom relevantné dôvody na to, aby páchatel'ovi zanikla trestnost' činu, ktorého sa dopustil. Trestnoprávna teória tieto dôvody zániku trestnosti označuje ako negatívne podmienky trestnej zodpovednosti, pretože aj napriek tomu, že páchatel' sa dopustil konania, ktorým ohrozil alebo porušil záujem chránený Trestným zákonom, nemusel znášat’ následky tohto konania. Teda ide o situáciu, kedy páchatel' už spáchal trestný čin, avšak skôr ako by sa o ňom právoplatne rozhodlo, nastanú dôvody v dikcii Trestného zákona, ktorého následkom je zánik práva štátu trestne stíhat' a potrestat' páchatel'a trestného činu. Teda tak ako spáchaním trestného činu vzniká trestnoprávny vzt'ah medzi páchatel’om a štátom, okamihom kedy nastanú dôvody zániku trestnosti, takýto trestnoprávny vzt’ah zaniká, čo znamená, že orgány činné v trestnom konaní nemôžu trestné stíhanie začat', ak už aj bolo začaté, tak nemožno v ňom pokračovat', čo má za následok zastavenie takéhoto konania. Teda na rozdiel od inštitútu okolností vylučujúcich protiprávnost', trestnoprávny vzt'ah vznikol, ale pri skutočnostiach, ktoré majú za výsledok zánik trestnosti, zároveň aj zanikol. Pri inštitúte okolnosti vylučujúcich protiprávnost', naopak trestnoprávny vzt'ah ani nevznikne. ${ }^{5}$

5 IVOR, Jaroslav, Peter POLÁK a Jozef ZÁHORA. Trestnéprávo hmotné I. V šeobecná čast'. Bratislava: Wolters Kluwer (Iura Edition), 2016, s. 337. 
Podmienky účinnej l'útosti možno rozdelit' do dvoch vel'kých skupín, a to na všeobecné podmienky účinnej l'útosti pre taxatívne vymenované trestné činy ( $\int 85$ TZ) a osobitné ustanovenia o účinnej l'útosti ( 886 TZ). V trestnoprávnej úprave platnej do konca roka 2005 boli tieto osobitné formy účinnej l’útosti uvedené v osobitnej časti Trestného zákona, následne po skutkovej podstate trestného činu, ktorého sa týkali. V rámci novej úpravy Trestného zákona, sú tieto ustanovenia zaradené v rámci všeobecnej časti Trestného zákona. Máme za to, že zákonodarca sa pokúšal o sprehl’adnenie dôležitých inštitútov trestného práva, čo účinná l’útost' plne predstavuje. Z hl’adiska zamerania príspevku sa budeme venovat' najmä podmienkam účinnej l'útosti podl'a $\int 86$, ked’že zohl'adňujú možnost' zániku trestnosti v daňovej trestnej činnosti. Teda ide o špeciálne ustanovenie, ktoré obsahuje pre každý trestný čin osobitne špeciálne podmienky, ktoré musia byt' splnené, aby k zániku takéhoto trestného činu došlo.

Samotné zákonné znenie účinnej l'útosti podl’a $\int 85$ TZ je nasledovné: „Trestnost’ trestných čnov zaniká, ak páchatel' dobrovol'ne:

a) škodlivý následok trestnébo činu zamedzil alebo napravil, alebo

b) urobil o trestnom čine oznámenie v čase, ked’ sa škodlivému následku trestného činu mohlo ešte zabránit; oznámenie treba urobit’ orgánu činnému v trestnom konani alebo Policajnému zboru, vojak môže toto oznámenie urobit' aj svojmu nadriadenému alebo sluð̌obnému orgánu a osoba vo výkone trestu odňatia slobody alebo vo výkone väzby aj príslušníkovi Zboru väzenskej a justičnej strážè. "

Špeciálne ustanovenie zahŕňa omisívne trestné činy, ktoré možno spáchat' nesplnením zákonnej povinnosti. Podstatu týchto osobitných foriem účinnej l'útosti tvorí skutočnost', že spoločnost' dáva prednost' dodatočnému splneniu povinnosti, z nesplnenia ktorých vznikli štátu alebo osobám podlžnosti, pred potrestaním páchatel'a. Ciel’om je snaha uviest' spôsobené škodlivé následky do žiaduceho stavu, v našom prípade teda ide o to, aby osoby s daňovou povinnost’ou uhradili štátu dane. Zároveň sa tým páchatel’ovi dáva posledná možnost', aby dodatočne splnil svoje povinnosti v lehotách presne ustanovených v zákone, inak bude nasledovat' trestnoprávny postih. Základnou podmienkou je, že páchatel' dodatočne splní svoje povinnosti v celom rozsahu, t.j. že páchatel' vyplatí celú dlžnú sumu. Rovnaké účinky má aj to, ak zariadi, aby dlžnú sumu za neho uhradila iná osoba, napríklad ak banka vyplatí dlžnú sumu. Stačí aj to, že páchatel’ sa pričiní o to, aby bola povinnost' dodatočne splnená inou osobou, napríklad požiada kamaráta, aby sa neho zaplatil a ten to urobí. Upozornit' treba na skutočnost', že na zánik trestnosti nestačí len čiastočné splnenie povinnosti, prísl'ub splnenia povinnosti v budúcnosti alebo uzavretie dohody o neskoršom splnení povinnosti naraz alebo postupne. V uvedených prípadoch nepôjde o účinnú l'útost' ani vtedy, ak by oprávnená osoba splnenie povinnosti povinnej osobe odpustila.

Tieto podmienky teda určujú zánik trestnosti pre tzv. omisívne trestné činy, teda ide o to, že páchatel' opomenul konanie, ktoré bol povinný vykonat' v zmysle zákonne splnených podmienok, $v$ našom príde išlo o peňažné plnenie, ktoré páchatel'ovi plynulo 
z daňovoprávnych vzt’ahov medzi štátom, resp. územnou samosprávou a daňovníkom, resp. subjektom dane. Zmyslom týchto ustanovení je prísl'ub beztrestnosti páchatel'a $\mathrm{k}$ dodatočnému plneniu podlžnosti či už voči štátu alebo určitým osobám.

Podmienkou prísl'ubu beztrestnosti je však splnit' dodatočne svoju povinnost' v celom rozsahu. Musí priamo on alebo cez tretiu osobu, ktorú požiada, uhradit' dlžnú povinnost'. Teda musí dôjst' k úplnému zaplateniu dlžnej sumy, bez rozdelenia. Nestačí ani dohoda medzi páchatel’om a oprávnenou osobou, že dlžná suma bude uhradená, rovnako nestačí sl'ub o zaplatení v budúcnosti (R44/1972).

Páchatel'ovi sa teda dáva posledná možnost', aby dodatočne splnil svoju povinnost' v lehote presne v zákone ustanovenej (najneskôr v nasledujúci deň po dni, ked' sa páchatel' po skončení jeho vyšetrovania mohol oboznámit’ s jeho výsledkami), inak bude nasledovat' trestnoprávny postih, aj v tomto prípade spoločnost' dáva prednost' splneniu povinnosti, hoci i dodatočnému, z nesplnenia ktorej by vznikli štátu podlžnosti, pred potrestaním páchatel'a.

Trestný zákon explicitne upravuje aj inštitút účinnej l'útosti v daňovej trestnej činnosti v $\int 86$ ods. 1 písm. e) v znení „trestnost’ trestného čnu zanikáa aj vtedy, ak ide o trestný čin skrátenia dane a poistnébo podl'a \276, neodvedenia dane a poistnébo podl'a \ 277 alebo nezaplatenia dane a poistnébo podl'a \278, ak splatná dañ a jej príslušenstvo alebo poistné boli dodatočne zaplatené najneskôr v nasledujúci deň po dni, ked'sa páchatel' po skončení jeho vy̌́strovania

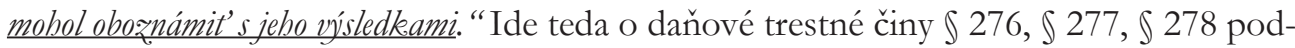
mieňujúc zánik trestnosti, je nevyhnutnou požiadavkou, že „splatná daň a jej príslušenstvo alebo poistné boli dodatočne zaplatené najneskôr v nasledujúci deñ po dni, ked'sa páchatel’ po skončeni jeho vyšetrovania mohol oboznámit's jeho výsledkami."

Táto podmienka podl'a \86 ods. 2 Trestného zákona sa však nevzt'ahuje na taký trestný čin, ktorého sa dopustil páchatel’, ktorý „,bol za obdobný rin v predchádzajúcich dvadsiatich śtyroch mesiacoch postibnutý, alebo ak trestné stíhanie páchatel'a za obdobný čin bolo v predchádzajúcich dvadsiatich štyroch mesiacoch zastavené z. dôvodu zániku trestnosti trestnébo činu podl'a odseku 1." To znamená, že páchatel' môže vyžit' inštitút účinnej l'útosti, avšak musí prejst' najmenej dvadsat'štyri mesiacov od predchádzajúceho postihnutia alebo dvadsat’štyri mesiacov, od kedy mu zanikla trestnost' trestného činu podl'a \86 ods.1 Trestného zákona.

'Trestnost' skrátenia dane a poistného podl’a \ 276 nezaniká, ak ide o páchatel'a, ktorý bol za obdobný čin v predchádzajúcich dvadsiatich štyroch mesiacoch postihnutý, alebo ak trestné stíhanie páchatel'a za obdobný trestný čin bolo v predchádzajúcich dvadsiatich štyroch mesiacoch zastavené z dôvodu zániku trestnosti \ 86 ods.1 písm. e). Postihnutým za obdobný čin sa rozumie ten, komu bola za obdobný čin uložená sankcia alebo iné opatrenie za priestupok alebo iný obdobný delikt. To však neplatí, aj je uložená sankcia lebo iné opatrenie zahladené (\$ 128 ods. 5). Obdobný činom sa rozumie čin rovnakého druhu, v tomto prípade hociktorý priestupok podla daňových predpisov. 


\section{Zákonná úprava inštitútu účinnej l'útosti v Českej republike}

Inštitút účinnej l'útosti v Českej republike výrazne sa neodlišuje zákonnej úpravy trestného zákona z roku 1961. Teda zákon č. 40/2009 Sb. Zákon Trestní zákoník upravuje v \33 inštitút účinnej l'útosti nasledovne: „trestná zodpovednost' za trestné činy ... skrátenie dane, poplatku a podobnej povinnej platby (I 240), nesplnenie oznamovacej povinnosti v dañovom konani (』 243),... zaniká, jestliže pachatel dobrovolně

a) škodlivému následku trestnébo činu zamezil nebo jej napravil, nebo

b) učinil o trestném činu oznámeni v době, kedy škodlivému následku trestnébo činu moblo být ještè zabránèno; oznámení je nutno učinit státnímu zástupci nebo policejnimu orgánu, voják mùže misto toho učnit oznámeni nadríżenému."

Táto všeobecná formulácia účinnej l'útosti je doplňnaná i špecifickým ustanovením o účinnej l'útosti, ktoré sa nachádza v osobitnej časti Trestného zákoníka, pojednávajúcej o trestnom čine neodvedenia dane, poistného na sociálne zabezpečenie a podobnej povinnej platby (\$241), v znení ,zaniká, jestliže pachatel svou povinnost dodatečnè splnil drüve, než soud pruníbo stupně počal vyblašovat rozsudek".

Možno konštatovat', že v prípade českej i slovenskej zákonnej úpravy inštitútu účinnej l'útosti je zjavné, že obidve úpravy vychádzali z trestného zákona z roku 1961. Teda všeobecné ustanovenie o účinnej l'útosti je priam totožné, až na doplnenie v slovenskom Trestnom zákone, komu môže podat' oznámenie osoba vo výkone trestu odňatia slobody alebo vo výkone väzby. Najväčší rozdiel možno badat' v špeciálnom ustanovení o účinnej l'útosti a to najmä $\mathrm{v}$ prípade, kde sa toto ustanovenie $\mathrm{v}$ rámci právneho predpisu nachádza. Český trestný zákoník ostal pri pôvodnej koncepcii, teda toto ustanovenie je súčast’ou osobitnej časti právnej úpravy. Slovenský Trestný zákon naopak špeciálne ustanovenie o účinnej l'útosti subsumoval pod všeobecné ustanovenie o účinnej l'útosti, pričom značne sprehl’adnil úpravu samotného inštitútu. Ak však porovnáme samotné znenie tohto ustanovenia, je možné vnímat' mnohé odlišnosti, a to najmä v tom, pri ktorých trestných činoch je prípustná účinná l’útost'.

Najlepšie je to možné vnímat' v prípade trestného činu skrátenia dane. Zatial čo český Trestní zákoník pripúšt’a len všeobecnú formu účinnej l’útosti, kde dôležitým prvkom je najmä princíp dobrovol’nosti, slovenský Trestný zákon pripúšt’a i aplikáciu špeciálneho ustanovenia o účinnej l'útosti, kde princíp dobrovol'nosti značne absentuje. Na druhej strane však samotná formulácia špeciálneho ustanovenia v českom Trestnom zákoníku je zjavne vol'nejšia, pretože páchatel' má svoju povinnost' dodatočne splnit' skôr, ako súd prvého stupňa začal vyhlasovat' rozsudok.

\section{7 Účinná l'útost'v náleze Ústavného súdu SR}

I napriek tomu, že tento nález Ústavného súdu SR I. ÚS 212/2017-65 (d’alej st’ažnost') rozhodol, že práva podl’a čl. 46 ods.1 a čl. 50 ods.3 a 6 Ústavy Slovenskej republiky, z. 
č. 460/1992 Zb. v znení neskorších predpisov (d’alej Ústava SR), ako aj práva zaručené v čl. 6 ods. 1 a 3 písm. c) Dohovoru o ochrane l'udských práv a základných slobôd porušené neboli, v odôvodnení možno nájst’ zaujímavé právne vety týkajúce sa aj inštitútu účinnej l'útosti. Zo st'ažnosti vyplýva, že st'ažovatel' bol uznaný vinným zo spáchania pokračovacieho trestného činu neodvedenia dane a bol odsúdený na dva roky s podmienečným odkladom $\mathrm{v}$ skúšobnej dobe dva roky a mal povinnost' uhradit' poškodenému škodu (v tomto prípade poškodeným je štát ako správca dane) v sume $1031 €$, načo sa st’ažovatel' odvolal a v konaní pred najvyšším súdom mu bol vymeraný už len peňažný trest vo výške $20000 €$, pričom pre prípad úmyselného marenia výkonu tohto trestu mu uložil aj náhradný trest odňatia slobody v trvaní jedného roka a povinnost' nahradit' poškodenému škodu v sume $573 €$. Proti postupu a rozsudku krajského súdu ako aj postupu a rozsudku najvyššieho súdu podal st'ažovatel' opät' ústavnú st'ažnost', ktorá bola odmietnutá z dôvodu neprípustnosti a zjavnej neopodstatnenosti, ked’že namietal porušenie práva na prerokovanie veci bez zbytočných priet’ahov a konania pred súdom už boli právoplatne skončené. Čo je však z hl’adiska zamerania článku dôležité st'ažovatel' namietal pochybenie dovolacieho súdu, pretože neaplikoval neskorší 'Trestný zákon, ktorý bol podl'a st'ažovatel’a pre neho ako páchatel’a priaznivejší, a to najmä z hl’adiska ustanovení o účinnej l'útosti. St’ažovatel' uvádza, „ře odvolaci súd sa s touto námietkou vysporiadal tak, že poukázal na \148a Trestnébo zákona účnnébo do 31. 12. 2005 a na to, že za tento trestný čin bola stanovená sadz̧ba trestu odñatia slobody na 2 až 8 rokov, oproti trestnej sadz̧be za trestný čin podl'a \277 ods. 1, ods. 2 Trestnébo zákona účinnébo od 1. 1. 2006, ktorá stanovuje trestnú sadz̧bu na 3 až 8 rokov. Z toho usúdil, že pre st'ažovatel'a je priaznivejš zákon účinný do 31. 12. 2005, v súvislosti s tým potom odkázal na ustanovenie \66 pism. a) tohto zákona, ktoré ako podmienku účinnej l'útosti stanovovalo, aby páchatel' dobrovolne škodlivý následok trestnébo činu zamedzil, alebo napravil... " Podl'a st'ažovatel'a mal byt' jeho prípad posúdený podl'a Trestného zákona účinného od 1.januára 2006 z dôvodu pre neho priaznivejšie ustanovenie \ 86 ods.1 písm. e) o účinnej l'útosti, v zmysel ktorého zaniká trestnost' trestného činu „... skerátenia dane a poistnébo podl'a \276, neodvedenia dane a poistnébo podl'a \277 alebo nezaplatenie dane a poistného podl'a $\int 278$, ak splatná daň a jej príslušenstvo alebo poistné boli dodatočne zaplatené najneskôr v nasledujúci deň po dni, ked' sa páchatel' po skončení jeho vyšetrovania mohol oboznámit's jeho výsledkami... "

St'ažovatel' uprednostňoval teda skôr nový 'Trestný zákon, kde je síce vyššia sadzba, avšak inštitút účinnej l'útosti je upravený ovel'a vol'nejšie ako v prípade predchádzajúceho Trestného zákona, kde trestná sadzba bola nižšia, ale inštitút účinnej l'útosti bol vel'mi striktne upravený. Teda st'ažovatel' uviedol, že súd síce použil výhodnost' nižšej sadzby, avšak „bez výżamu pri dobrodeni, k.toré pre st’ažovatel’a vyplýva z. neskoršieho právneho predpisu - zániku trestnosti činu. "St’ažovatel' vedel, že nie je možné využit' účinnú l'útost' podl’a neskoršej úpravy, pretože na zánik trestnosti činu je potrebný prvok „dobrovol'nosti“ odstránenia alebo zamedzenia škodlivému následku, čo v tomto prípade 
u st’ažovatel'a absentovalo, pretože škodlivý následok napravil až ked’ bol pod tlakom trestného stíhania, presnejšie pod vplyvom väzby.

$\mathrm{Na}$ základe žiadosti ústavného súdu sa $\mathrm{k}$ veci za najvyšší súd písomne vyjadrila jeho predsedníčka a zákonný sudca v danej veci listom č. KP 3/217-36 z 12. júna 2017. Dôležité skutočnosti týkajúce sa vyššie spomínanej problematiky zákonný sudca najvyššieho súdu vyhodnotil najmä v úvahe o použití priaznivejšieho zákona, pričom poznamenal, že je potrebné zopakovat', že obvinený sa dopustil dvoch trestných činov, ktoré oba je možné posúdit' len podl'a rovnakého zákona. Nie je možné každý trestný čin posúdit', v spoločnom konaní, podl’a dvoch rôznych zákonov, pokial’ je jeden predpis priaznivejší pre prvý trestný čin a d'alší predpis priaznivejší pre druhý trestný čin. „Ďaľsou skutočnostou bolo, žre v dovolacom konani už nie je možné preskúmat' primeranost' výšky trestu, pokial' je uložený $v$ rámci zákonnej sadz̧y “. A čo sa týka inštitútu účinnej l’útosti uviedol nasledujúci záver, a to, že účinná l'útost' sa vo vzt'ahu $\mathrm{k} \int 86$ písm. d) Trestného zákona na konanie nevzt'ahuje, „ak splatná daň a jej príslušenstvo boli dodatočne zaplatené najskôr..." Avšak aj odvolací súd podriadil skutkový stav pod právnu vetu „neoprávnene uplatnil nárok na vrátenie dane zpridanej hodnoty a taký čn spáchal vo vä̌rsom rozsabu. "Teda \ 277 ods. 1 predpokladá dve formy konania, ktoré predpokladajú konanie v malom rozsahu. A na druhej strane sa \ 277 ods. 2 osamostatnil novelou od 11. októbra 2009 ako \277a TZ daňový podvod, na ktorého sa inštitút účinnej l'útosti nevzt'ahuje.

Podl'a st'ažovatel'a totiž pri vyhodnotení pre neho výhodnejšej právnej úpravy nebolo postačujúce, že súdy konajúce $\mathrm{v}$ jeho veci konfrontovali Trestný zákon účinný pred a po 1. 1. 2006 iba $z$ hl'adiska rozsahu zákonnej trestnej sadzby trestu odňatia slobody za označený trestný čin, ale bolo potrebné konfrontovat’ aj ustanovenia týchto právnych úprav o účinnej l'útosti. Ked’že po skončení vyšetrovania podal dodatočné daňové priznanie, a teda mal spĺňat’ zákonné požiadavky pre zánik trestnosti jemu za vinu kladeného trestného činu neodvedenia dane, avšak podl'a \66 o účinnej l'útosti TZ účinného do 31. 12. 005 zákonné podmienky pre zánik trestnosti tohto trestného činu nespĺňal, ked'že prvok dobrovol'nosti absentoval. Dovolací súd námietku st'ažovatel’a odôvodnil takto: „naplnenie tohto dovolacieho dôvodu obvinený videl aj v tom, že súdy oboch stupnov mali apli-

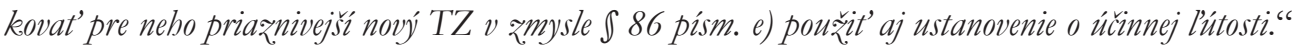
Obvinený v tomto smere poukázal na to, že podal dodatočné daňové priznania k DPH. Vo veci vykonané dokazovanie (skutkové zistenia) bolo z ich strany vyhodnotené tak, že obvinený sa oboch trestných činov dopustil, pričom zároveň bolo konštatované, že u obvineného podmienky účinnej l'útosti splnené neboli (a preto trestnost' činu nezanikla).

Najdôležitejšie je z toho pohl'adu upozornit' na skutočnost', že trestná sadzba za trestný čin neodvedenia dane a poistného podl'a $\int 148 \mathrm{a}$ ods. 1, ods. 2 TZ v znení účinnom od 1. 1. 2006 je miernejšia (sadzba 2 až 8 rokov odňatia slobody) s tým, že je žiaduce dodat', že obvinenému bol ukladaný trest za súbeh trestných činov a teda podl’a toho 
zákonného ustanovenia, ktoré sa vzt'ahuje na trestný čin z nich najprísnejšie trestný. Navyše dovolací súd len na okraj k tomu dodal, že miernejší trestný čin daňového podvodu bol do trestného zákona \277a zavedený až s účinnost’ou od 1. 10. 2012, a teda po právoplatnom skončení veci.

V tejto súvislosti je nutné prisvedčit' obrannej argumentácií dovolacieho súdu v konaní pred ústavným súdom, podl'a ktorej na prípad st'ažovatel'a nebolo a nie je možné aplikovat' ustanovenie $\int 86$ ods.1 písm. e) TZ účinného od 1. 1. 2006 o účinnej l'útosti, tak ako sa toho dožaduje st'ažovatel', pretože v jeho prípade krajský súd v odsudzujúcom rozsudku kvalifikoval ním spáchaný skutok právnou vetou, podl'a ktorej st’ažovatel', ... neoprávnene uplatnil nárok na vrátenie dane z pridanej hodnoty a taký čin spáchal vo väčšom rozsahu..., čím spáchal ... pokračujúci trestný čin neodvedenia dane podl’a \ 148 a ods. 1,2 TZ. Teda trestného činu sa nedopustí len ten, kto fakticky neodvedie (nezaplatî) učenému príjemcovi splatnú daň, ktorú zrazil, tak ako by sa to mohlo zdat' z označenia tejto skutkovej podstaty, ale tohto trestného činu sa dopustil aj ten, kto neoprávnene nie $\mathrm{v}$ malom rozsahu uplatní nárok na vrátenie dane..., tak ako to bolo v prípade st'ažovatel'a. Konanie st'ažovatel'a teda nespočívalo vo faktickom neodvedení splatnej dane, ktorú by tak v zmysle ustanovenia mohol dodatočne zaplatit', ale že si neoprávnene uplatnil odpočet DPH. Takže dodatočne nemal čo zaplatit', aby naplnil zákonnú dikciu účinnej l'útosti podl'a \ 86 ods. 1 písm. e) TZ účinného od 1. 1. 2006.

\section{8 Účinná l'útost'v náleze Ústavního soudu ČR}

I v Českej republike sa zdvihla odborná diskusia o otázke účinnej l'útosti, najmä potom, čo Ústavní soud Českej republiky, vo svojom náleze sp. zn. IV. ÚS 3093/08 spochybnil doterajší výklad inštitútu účinnej l'útosti, najmä v prípade posudzovania skrátenia dane a neodvedenia dane. Tento nález uviedol, že je neprípustné, aby lehoty pre uplatnenie účinnej l'útosti boli rozdielne pre trestný čin skrátenia dane a pre trestný čin neodvedenia dane. Teda nastal prípad, ked’ Ústavní soud vydal nález, ktorý odporoval doslovnému zneniu 'Trestného zákoníku, pretože pripúšt'al možnost' i v prípade skrátenia dane, aby pri účinnej l'útosti bolo možné akceptovat' absenciu princípu dobrovol'nosti, ktorú \ 33 expressis verbis nepripúšt'a. V dôsledku tohto nálezu, začali i iné súdy vydávat' rozhodnutia, ktoré boli síce $\mathrm{v}$ súlade $\mathrm{s}$ nálezom, no v rozpore s doslovným znením zákona. Napríklad Najvyšší soud ČR konštatoval, že analogicky je možné u trestného činu skrátenia dane použit' ustanovenie o špecifickej účinnej l'útosti u trestného činu neodvedenia dane. „Nesprávnost tohoto rozhodnutí je patrná již ze skutečnosti, že NS poǔ̌il na daný prípad jak zuláštni pröpad účinné litosti pro trestný čin neodvedeni daně (pokud jde o lhritu k. projeveni účinné litosti), tak obecnou účinnou lítost, která platí pro trestný čin zkeráceni daně (pokud jde o možnost naplnèní podminek účinné lítosti oznámením orgánu verejné moci). "Takto vyhotovené rozhodnutie by predstavovalo svojvôl’u realizácie práva, čoho si 11. senát Nejvyššího soudu všimol a vec predložil na posudzovanie súladu podl’a ustanovenia \ 20 ods. 1 zákona č. 6/2002 
Sb. o soudech a soudcích v znení neskorších predpisov. Výsledok vyslovený trestným kolégiom Nejvyššího soudu bol, že „dodatečné zaplaceni daněv prǒpadě trestnébo činu zkerácení danè neni diovodem pro analogické pouřití zuláštního ustanoveni účinné lítosti vatahujici se na trestný čin neodvedeni daně". Teda išlo o usmernenie, ktorého výsledok bol ten, že nad’alej sa postupovalo tak, že na trestný čin skrátenia dane sa aplikovala všeobecná účinná l'útost' podl'a \33 a na trestný čin neodvedenia dane sa používala aplikácia špecifickej účinnej l’útosti podl'a \ 242 Trestního zákoníku. ${ }^{6}$

Rovnako v roku 2013 Nejvyšší soud podal výklad v rozhodnutí č. 29/2013 Sb. rozhod.tr., kde opät' nadviazal na doterajšiu líniu rozhodovania, a to tak, že páchatel’ovi môže zaniknút' zodpovednost' za trestný čin skrátenia dane len v prípade, že splní dôležitú požiadavku dobrovol’nosti.

\section{Záver}

Koncepcia vyvažovania fiskálnej a represívnej funkcie v daňovom práve je ústrednou témou celého Daňového poriadku. Na základe analýzy sme dospeli k záveru, že v značnej miere fiskálna funkcia prevažuje nad represívnou, z čoho vyplýva, že štát na jednej strane síce používa prostriedky na splnenie povinnosti, ale daňovému subjektu vždy ponecháva možno napravit' svoje konanie a svoju daňovú povinnost' dodatočne splnit'. Hoci Daňový poriadok umožňuje daňovému subjektu si riadne splnit' svoju povinnost', správca dane však neopomína potrestat' páchatel'a. Za najlepší príklad by sme uviedli možnost' určenia dane podl'a pomôcok, teda v prípade, že daňový subjekt opomenie plnenie svojich povinnosti, ktoré mu vyplývajú z daňovoprávnych vzt’ahov, čo v konečnom dôsledku má za následok, že nemožno daň zistit' správne ani prostredníctvom daňovej kontroly. Správca dane sám podl'a prípustných pomôcok, presne definovaných v zákone, určí daň daňovému subjektu. Správca dane vyrubí daň za daňový subjekt, čo môže navodzovat' dojem dominancie fiskálnych záujmov štátu, na druhej stráne však zároveň správca dane uloží daňovému subjektu pokutu podl'a \ 154 ods.1 písm. a) v spojení s \ 155 ods. 1 písm. a) a b) Daňového poriadku. Teda namiesto toho, aby jednoducho daňový subjekt potrestal a čakal kedy daňový subjekt splní svoju povinnost', prevezme za neho toto „bremeno“ a určí za daňový subjekt výšku daňovej povinnosti. V neposlednom rade nesmie správca dane zabudnút’ ani na $\int 46$ ods. 5, ktorý zdôrazňuje, že pri určení dane podl’a pomôcok je správca dane povinný prihliadnut' tiež na zistené okolnosti, z ktorých vyplývajú výhody pre daňový subjekt, aj ked' ním neboli uplatnené.

Ak sa však daňový subjekt dopustí konania, ktoré spĺňa znaky správneho deliktu podl’a \154 Daňového poriadku, uloží mu správca dane pokutu alebo úrok z omeškania.

Daňový subjekt však môže natol'ko ohrozit' alebo poškodit' chránený záujem, finančný nárok štátu, že je nevyhnutné jeho konanie posudzovat’ prostredníctvo prostriedkov

6 Uznesenie Najvyššieho súdu SR, sp. zn. 5 Tdo 743/2013. 
trestného práva. Trestný zákon exaktne vymedzuje skutkové podstaty, ktorými sa daňový subjekt - páchatel' môže dopustit’ trestného činu. Čo však môže byt' zarážajúce, že i napriek dôležitosti chráneného záujmu i Trestný zákon poskytuje možnost' páchatel'ovi ešte svoj skutok napravit', čím by sa jeho konanie stalo beztrestné. Opät' možno uvažovat' nad tým, či i Trestný zákon, presnejšie trestné činy daňové, prevzal myšlienku vyvažovania fiskálnej a represívnej funkcie. Práve inštitút účinnej l’útosti je tým dôležitým argumentom v prípade „vít’azstva“ fiskálnej funkcie nad represívnou. Štát dáva možnost’ páchatel'ovi napravit' svoje konanie, čím sa opät' jeho konanie môže stat' beztrestným.

Ciel’om nášho príspevku bola komplexná analýza práve inštitútu účinnej l'útosti, a to nielen prostredníctvom dostupnej literatúry, zákonného znenia, ale aj prostredníctvom činností súdov ako i komparáciou s iným štátom, ktorý tento inštitút pripúšt’a. Pri vyvodení dôležitých záverov je potrebné zdôraznit' najmä historický exkurz, ked’že v rámci slovenského Trestného zákona došlo k výraznej zmene podmienok najmä pri špecifickom ustanovení o účinnej l'útosti. Za vel'mi pozitívne hodnotíme, že problematika účinnej l’útosti sa nachádza na jednom mieste v právnej úprave, čo zaručuje explicitnú prehl'adnost'.

Následnou komparáciou slovenského Trestného zákona a českého Trestního zákoníka sme zistili, že je zjavné, že právne úpravy obidvoch štátov pôvodom vychádzajú z toho istého Trestného zákona z 1961 a jeho neskorších noviel, resp. d’alších Trestných zákonov, čo sa prejavilo tak, že samotný text všeobecného ustanovenia účinnej l'útosti vykazuje značnú zhodu. $\mathrm{Na}$ druhej strane špeciálne ustanovenie o účinnej lútosti, má každý štát upravené rozdielne, a to najmä v dvoch dôležitých aspektoch.

Po prvé je dôležité upriamit' pozornost', na ktoré daňové trestné činy sa ustanovenie o účinnej l'útosti vzt’ahuje. V prípade českého Trestního zákoníku, sú daňové trestné činy striktne rozdelené na omisívne a komisívne, pričom špeciálne ustanovenie účinnej l'útosti sa vzt'ahuje len na omisívny daňový trestný čin neodvedenia dane. Zatial' čo slovenský Trestný zákon pripúšt’a tak omisívne ako i komisívne daňové trestné činy, teda vrátane skrátenia dane a poistného. Vel’mi interesantný pohl’ad na danú problematiku priniesol do tejto problematiky nález Ústavního soudu sp. zn. IV. ÚS 3093/08. Ten spochybnil doterajší výklad inštitútu účinnej l'útosti, najmä v prípade posudzovania skrátenia dane a neodvedenia dane. Tento nález uviedol, že je neprípustné, aby lehoty pre uplatnenie účinnej l'útosti boli rozdielne pre trestný čin skrátenia dane a pre trestný čin neodvedenia dane. Teda nastal prípad, ked' Ústavní soud vydal nález, ktorý odporoval doslovnému zneniu 'Trestného zákoníku, pretože pripúšt'al možnost' i v prípade skrátenia dane, aby pri účinnej l'útosti bolo možné akceptovat' absenciu princípu dobrovol'nosti, ktorú \ 33 expressis verbis nepripúšt’a. Vo svojej argumentácií uvádza, že pojem „neodvedenia“ je značne terminologicky širší, a teda v konečnom dôsledku v sebe zahŕna i samotný trestný čin skrátenia dane. Okrem toho Ústavní soud poukázal, že $\int 33$ Trestního zákoníku neobsahuje lehotu na prejavenie účinnej l’útosti. 
Ak už sme pri lehote na prejavenie účinnej l'útosti, zákonné úpravy obidvoch štátov sa značne rôznia. Trestný zákon v špeciálnom ustanoveni účinnej l'útosti pripúšt'a lehotu v dikcii „najneskôr v nasledujúci deñ po dni, ked’ sa páchatel' po skončeni jeho vyšetrovania mohol oboznámit's jeho výsledkami... "Na druhej strane český Trestní zákonník pripúšt'a lehotu v dikcii „splnil dřve, nežz soud prvního stupně pořal vyblašovat rozsudek." V tomto prípade je zákonné znenie do značne miery benevolentnejšie.

Existujú názory ${ }^{7}$, že koncepcia účinnej l'útosti je vel'mi vol'ne koncipovaná a štát má vel'mi vel’a dôvodov na to, aby uprednostnil fiskálnu suverenitu štátu pred kategorickým potrestaním páchatel’a, ako napríklad: nárast verejných financií, šetrenie štátnych finančných prostriedkov za proces, predchádzanie sprenevery daňových výnosov, a pod. Dochádza i k určitým omylom, ako napríklad v prípade nálezu Ústavního soudu, ktorý podl'a Pelca ${ }^{8}$,se bohužel vỉbec nevyporádal s dosavadni judikaturou, a to jak judikaturou NS, tak svou vlastni judikaturou, nebot' sám ÚS do té doby zastával, že na trestný čin zkeráceni daně se vztahuje obecná úcinná lítost podle \33 trestního zákoníku. "Napriek takémuto nálezu Ústavního soudu súdna prax nad’alej zastáva pôvodnú a teda zákonnú líniu uplatnenia účinnej l'útosti a to, že páchatel'ovi môže zaniknút' zodpovednost' za trestný čin skrátenia dane len v prípade, že splní dôležitú požiadavku dobrovol’nosti.

$\mathrm{Na}$ základe vyššie uvedených skutočností je namieste vyzdvihnút', že dôležitú úlohu v prípade aplikácie inštitútu účinnej l'útosti majú najmä súdy, aby bolo striktne dodržiavané základné l'udské právo podl’a čl. 46, právo na spravodlivý súdny proces. I z toho dôvodu sme sa venovali nálezom Ústavného súdu, ktoré potvrdzujú a zdôrazňujú nielen prostriedok ochrany ústavnosti, ale najmä dodržiavania základných práv a slobôd. Paradoxne práve nález Ústavného súdu je dôkazom, že ak funguje súdnictvo na princípe spravodlivosti a dodržiavania zákon, nie je možné inštitút účinnej l'útosti „zneužit““ vo svoj prospech a subsumovat' konanie páchatel'a pod taký trestný čin, aby inštitút účinnej l'útosti bol zneužitý.

7 HENCOVSKÁ, Mária. Uprednostnenie splnenia povinnosti pred trestným postihom v daňovej trestnej činnosti. In: Teória a prax verejnej správy. Zbornik príspevkov z vedeckej konferencie s medzinárodnou úcastou organižovanej Fakultou verejnej správy UPJŠ v Košiciach 16-17. 10. 2008. Košice: Univerzita Pavla Jozefa Šafárika, 2009, s. 435.

8 PELC, Vladimír. Účinná lístost u trestného činu zkrácení dane a aktuálny stav judikatury. In: Bulletin advokacie, 2014, č. 4. s. 36. 